\title{
ANALISIS TENTANG SISTEM PERADILAN AGAMA DI INDONESIA
}

\section{Domiri}

\author{
* Pengadilan Tinggi Agama, Palembang \\ Korespondensi: dmrfarokha4@gmail.com \\ Naskah dikirim: 22 Maret 2016 \\ Naskah diterima untuk diterbitkan: 20 Mei 2016
}

\begin{abstract}
Religious Court serves as the judicial system in Indonesia, in addition it is also a subsystem of the Indonesian judicial system. The Indonesian judicial system is composed of several subsystems, such as, Religious Court, Commercial Court, Military Court, and the Administrative Court. As a judicial system, the Religious Court has several sub-systems or component. Its components are: first, the law itself, which includes procedural and substantive law. Secondly, the apparatus of the court, including judges, clerks, and bailiffs. Each of these components has their own duty and function. The law serves as the guideline for all the officials of the Religious Court in carrying out their duties and functions. The judge assigned to make a judgement, to watch, to listen, to examine, and to decide the appointed casse. The Clerk is charged to record the proceedings and executes the court decision/execution. The Bailiff's duty is to execute the commands of Chairman and execute seizure on the orders of Chief of the Court. All these components work synergistically in achieving a goal that is the law and justice are regarded as the most supreme power.
\end{abstract}

Keywords: religious court, judicial system, Indonesia

\begin{abstract}
Abstrak
Pengadilan Agama adalah sebuah sistem Peradilan, tetapi sekaligus juga sebagai sub sistem dari sistem peradilan Indonesia, karena sistem peradilan Indonesia terdiri dari sub sistem Peradilan Agama, Peradilan Umum, Peradilan Milter dan Peradilan Tata Usaha Negara. Sebagai sistem peradilan, Pengadilan Agama memiliki beberapa sub sitem atau beberapa kompenen. Komponen Peradilan Agama terdiri dari: Pertama, aturan hukum, yang meliputi hukum acara dan hukum materiil. Kedua aparatur Pengadilan Agama yang meliputi hakim, paniera dan juru sita. Masing-masing komponen tersebut mempunyai tugas dan fungsisendirisendiri. Aturan hukum berfungsi untuk menjadi petunjuk bagi semua aparat peradilan agama dalam menjalankan tugas dan fungsinya. Hakim bertugas untuk mengadili, memeriksa, dan memutus perkara yang diajukan kepadanya. Panitera bertugas untuk mencatat jalannya persidangan dan menjalankan putusan pengadilan/eksekusi. Juru sita bertugas untuk menjalankan perintah Ketua Sidang dan menjalankan sita atas perintah Ketua Pengadilan. Semua komponen tersebut bekerja untuk mencapai sebuah tujuan yakni tegaknya hukum dan keadilan.
\end{abstract}

Kata kunci: pengadilan agama, sistem peradilan, Indonesia 


\section{A. Pendahuluan}

Dalam ilmu hukum terdapat istilah sistem hukum. Untuk mengenal lebih dalam mengenai istilah sistem hukum maka kita lebih dahulu harus mengenal istilah "sistem". Istilah "sistem" berasal dari bahasa Yunani "systema" yang mengandung arti keseluruhan (a whole) yang terdiri dari banyak bagian. Systema juga berarti, hubungan yang berlangsung di antara satuan-satuan atau komponen secara teratur. ${ }^{1}$ Sedangkan definisi "sistem" menurut Bartalanffy yang dikutip oleh Lili Rasjidi adalah a complex ofelements in mutual interaction. ${ }^{2}$ Sistem diartikan sebagai suatu komplek elemen dalam suatu kesatuan interaksi. Kemudian definisi " sistem" menurut Campbell yang dikutip oleh Tatang Amirin adalah "we might define a system as any group of interrelated component or parts which function together to achieve a goal.." Yang artinya bahwa sistem itu merupakan himpunan komponen atau bagian yang saling berkaitan yang bersama-sama berfungsi untuk mencapai suatu tujuan.

Menurut Soerjono Soekanto ${ }^{3}$ faktor-faktor yang relevan untuk dibahas dalam masalah sistem adalah : (1) elemen-elemen suatu sistem (2) pembagian sistem, (3) konsistensi, (4) pengertian-pengertian dasar (grondbegrippena) dari sistem.

Menurut Winardi ${ }^{4}$, sistem ada dua macam yakni sistem terbuka dan sistem tertutup. Sistem terbuka adalah sebuah sistem yang mempunyai hubungan dengan lingkungan. Sedangkan sistem tertutup adalah sistem yang terisolasi dari lingkungan.

Setelah mengetahui istilah dan pengertian sistem, tidak kalah pentingnya kita juga harus mengetahui tentang ciri-ciri "sistem". Ciri-ciri "sistem" menurut Ismail Saleh, ${ }^{5}$ adalah sebagai berikut : (1) saling keterkaitan antara satu komponen dengan komponen lain, saling membatasi tetapi juga saling memperkuat, (2) dinamis, tetapi tetap terjaga keserasian dan keseimbangannya, (3) terbuka, tetapi tetap tidak kehilangan eksistensinya dan identitasnya, (4) galir dalam arti tidak kaku, sehingga dapat menampung.

Menurut Solly Lubis, ${ }^{6}$ hukum merupakan suatu sistem, maka pendekatan yang dilakukan adalah pendekatan sistem dan bukan pendekatan kekuasaan. Oleh karena pembahasan masalah ini berkaitan dengan sistem hukum maka perlu dipahami juga mengenai pengertian sistem hukum.

1 Tatang M.Amirin, Pokok-Pokok Teori Sistem, (Jakarta: Rajawali Pers, 1996), hal 18

${ }^{2}$ Lili Rasjidi, I.B.Wyasa Putra, Hukum Sebagai Suatu Sistem, (Bandung: Mandar Maju, 2003),hlm.63.

3 Soerjono Soekanto dan Purnadi Purbacaraka,Sendi-Sendi Ilmu Hukum, (Bandung: Citra Aditya Bakti, 1993), hlm. 39.

4 Winardi, Pengantar Tentng Teori Sistem Dan Analisis Sistem, (Bandung: Mandar Maju),hlm. 10.

5 Ismail Saleh, Majalah Hukum Badan Pembinaan Hukum Nasional, Departemen Kehakiman, No.119, Edisi Khusus, hal 13

6 Solly Lubis, Ilmu Pengetahuan Perundang-Undangan, (Bandung: Mandar Maju Bandung, 2009), hal 5. 
Dalam menjelaskan tentang hukum sebagai suatu sistem, Sudikno Mertokusumo $^{7}$, mengatakan sebagai berikut:

Hukum merupakan sistem berarti bahwa hukum itu merupakan tatanan, merupakan suatu kesatuan yang utuh yang terdiri dari bagian-bagian atau unsur-unsur yang saling berkaitan erat satu sama lain. Dengan perkataan lain sistem hukum adalah suatu kesatuan yang terdiri dari unsur-unsur yang mempunyai interaksi antara satu sama lain dan bekerja sama untuk mencapai tujuan kesatuan tersebut. Kesatuan tersebut diterapkan terhadap kompleks unsur-unsur yuridis seperti peraturan hukum, asas hukum dan pengertian hukum.

Berdasarkan definisi sistem hukum tersebut di atas maka dalam sistem hukum terdapat unsur-unsur sebagai berikut : (1) adanya berbagai komponen, (2) adanya fungsi masing-masing komponen, (3) adanya saling ketergantungan dan saling hubungan antar komponen, (4) adanya keterpaduan antara komponen, (5) semua komponen mengarah kepada tujuan yang telah ditetapkan.

Peradilan Agama adalah sebuah sistem hukum, tapi juga dapat menjadi sub sistem hukum. Menjadi sistem hukum karena Peradilan Agama memiliki sub sistem atau bagian-bagian yang lebih kecil. Sub sistem ini bisa juga disebut unsur atau komponen. ${ }^{8}$ Peradilan Agama menjadi sub sitem hukum apabila dihadapkan pada sistem hukum yang lebih besar atau lebih luas, seperti jika Peradilan Agama dihadapkan pada "sistem peradilan Indonesia" maka Peradilan Agama menjadi sub sistem dari "sistem peradilan Indonesia " karena di dalam "sistem peradilan Indonesia" disamping terdapat unsur Peradilan Agama juga terdapat unsur Peradilan Umum, Peradilan Tata Usaha Negara dan Peradilan Militer.Oleh karena Peradilan Agama sebagai sistem hukum, maka Peradilan Agama harus memiliki komponen-komponen dan keseluruhan komponen tersebut harus memiliki tujuan yang jelas.Oleh karenanya perlu ditelusuri apa saja komponen-komponen dan tujuan dari sistem Peradilan Agama itu.

\section{Permasalahan}

Peradilan Agama sebagai salah satu dari empat lingkungan peradilan di Indonesia keberadaannya diakui secara hukum sejak dikeluarkannya UndangUndang Nomor 14 Tahun 1970. ${ }^{9}$ Sebagai lembaga peradilan negara, Peradilan Agama mempunyai kedudukan yang sederajat dengan lembaga peradilan lingkungan lainnya. Disamping itu Peradilan Agama juga berstatus sebagai suatu sistem hukum. Berdasarkan hal tersebut maka yang menjadi masalah

7 Sudikno Mertokusumo, Mengenal Hukum Suatu Pengantar, (Yogyakarta: Liberty, 1991), hlm. 102

${ }^{8}$ Amirin, Op. Cit., hlm. 33

9 Qodri Azizy, Eklektisisme Hukum Nasional Kompetisi Antara Hukum Islam dan Hukum Umum, (Yogyakarta: Gama Media, 2002), hlm. 144. 
adalah apa saja komponen-komponen Peradilan Agama tersebut dan apa fungsi dari masing-masing komponen itu dalam mendukung terciptanya tujuan dari didirikannya lemabaga Peradilan Agama itu.

\section{Pembahasan}

\section{Komponen Peradilan Agama}

Sebagaimana penulis sebutkan sebelumnya, bahwa istilah lain dari sub sistem adalah komponen, sehingga apabila dalam tulisan ini disebut komponen, yang dimaksud adalah sub sitem dari sistem Peradilan Agama. Seperti penjelasan sebelumnya bahwa suatu sistem hukum terdiri dari beberapa sub sistem atau beberapa komponen, maka Peradilan Agama sebagai suatu sistem hukum terdiri dari beberapa komponen.

Menurut Rochmat Sumitro, ${ }^{10}$ komponen peradilan terdiri dari 4 anasir, yakni : (1) adanya aturan hukum yang abstrak yang mengikat umum dan dapat diterapkan pada suatu persoalan, (2) adanya suatu perselisihan hukum yang konkrit, (3) ada sekurang-kurangnya dua pihak, (4) adanya aparatur peradilan yang berwenang memutuskan perselisihan.

Unsur-unsur yang disebutkan oleh Rochmat Sumitro di atas adalah unsur Peradilan yang berkaitan dengan proses penyelesaian terhadap suatu kasus tetentu, sehingga dalam unsur tersebut terdapat unsur "adanya perselisihan hukum yang konkrit" dan terdapat unsur "ada sekurang-kurangnya dua pihak”. Menurut pendapat penulis, dari 4 unsur tersebut yang menjadi unsur sistem Peradilan Agama adalah unsur ke satu dan ke empat yakni unsur " adanya aturan hukum yang abstrak yang mengikat umum dan dapat diterapkan pada suatu persoalan" dan unsur "adanya suatu aparatur peradilan yang berwenang memutuskan perselisihan," karena kedua unsur tersebut yang tidak dapat dipisahkan dari sistem Peradilan Agama. Oleh karenanya yang akan penulis bahas dalam tulisan ini hanya ke dua unsur tersebut.

\section{a. Aturan Hukum}

Sesuai dengan pendapat Rochmat Sumitro di atas bahwa elemen pertama Peradilan adalah adanya aturan hukum yang abstrak, yang mengikat umum dan dapat diterapkan pada suatu persoalan. Mengapa aturan hukum itu termasuk komponen dalam sistem Peradilan Agama karena Indonesia adalah negara hukum dan Peradilan Agama adalah salah satu lingkungan peradilan dalam sistem peradilan di negara Indonesia. Sementra itu salah satu ciri dari sebuah negara hukum ${ }^{11}$ adalah negara harus menjadikan hukum sebagai panglima.

\footnotetext{
10 Rochmat Soemitro, Masalah Peradilan Administrasi dan Hukum Pajak diIndonesia, (Bandung: Eresco, 1976), hlm. 7

11 Mengenai Negara hukum ini terdapat beberapa konsep. Konsep Negara hukum tersebut adalah sebagai berikut: a. Konsep negara hukum rechtstaat. Konsep ini berkembang di negara-negara Eropa Kontinental, konsep negara hukum tersebut, selanjutnya dikembangkan oleh Immanuel Kant, Friederich Julius Stahl, Laband, Buys, dan lain-lainnya. Ciri-ciri
} 
Aturan hukum yang ada di Peradilan Agama dari segi fungsinya terdiri dari hukum materiil dan hukum formil. Hukum formil adalah hukum yang mengatur bagaimana cara melaksanakan dan mempertahankan hukum materiil ${ }^{12}$ atau sering disebut hukum acara. Mengenai hukum formil yang berlaku di Pengadilan Agama disebutkan dalam Undang-Undang Nomor 71989 sebagai berikut:

Hukum Acara yang berlaku pada Pengadilan dalam lingkungan Peradilan Agama adalah hukum acara perdata yang berlaku pada Pengadilan dalam lingkungan Peradilan Umum, kecuali yang telah diatur secara khusus dalam undang-undang ini. ${ }^{13}$

Berdasarkan ketentuan pasal tersebut maka hukum acara yang berlaku di Pengadilan Agama sama dengan hukum acara yang berlaku di Pengadilan Negeri yakni HIR/RBg. Berlakunya HIR/RBg tersebut tidak untuk semua perkara yang menjadi kewenangan Pengadilan Agama, tetapi hanya berlaku atas perkara yang hukum acaranya belum diatur oleh Undang-Undang Nomor 7 Tahun 1989. Terhadap perkara yang sudah diatur oleh Undang-Undang Nomor 7 Tahun 1989 maka aturan hukum acara yang terdapat dalam HIR/RBg tidak berlaku di lingkungan

rechtstaat adalah (1) Perlindungan hak asasi manusia, (2) Pembagian kekuasaan, (3) Pemerintahan berdasarkan undang-undang(4)Peradilan Tata Usaha Negara.Jimly Asshiddiqie, Konstitusi dan Konstitutionalisme Indonesia (Jakarta: Sinar Grafika, 2004), hlm. 122. Kemudian konsep negara hukum yang lainnya adalah Rule of Law. Konsep ini lahir di Negara Anglo Saxon, pelopornya adalahA.C. Dicey seorang ahli dari Anglo Saxon, memberikan ciri Rule of Law sebagai berikut : (1) Supremasi hukum, dalam arti tidak boleh ada kesewenangwenangan sehingga seorang hanya boleh dihukum jika melanggar hukum.(2)Kedudukan yang sama di depan hukum, baik bagi rakyat biasa maupun bagi pejabat.(3) Terjaminnya hak-hak manusia oleh undang-undang dan keputusan-keputusan pengadilan.Munir Fuadi, Teori Negara Hukum Modern (rechttstaat) (Bandung: PT Refika Aditama, 2009), hlm. 10. Kemudian ciri negara hukum dari rechtsstaat dan rule of law diintegrasikan sehingga lahir ciri negara hukum yang baru Perumusan kembali ciri-ciri tersebut antara lain dihasilkan dari International Commision of Jurists pada konferensinya di Bangkok pada tahun 1965 menekankan bahwa disamping hak-hak politik bagi rakyat, harus diakui pula adanya hak-hak sosial dan ekonomi, sehingga perlu dibentuk standar dasar sosial ekonomi. Komisi ini dalam konferensi tersebut juga merumuskan syarat-syarat pemerintahan yang demokratis dibawah Rule ofLaw (yang dinamis ) sebagai berikut : (1) Perlindungan konstitusional, artinya selain menjamin hak-hak individu, konstitusi harus pula menentukan cara prosedural untuk memperoleh perlindungan atas hak-hak yang dijamin.(2) Badan kehakiman yang bebas dan tidak memihak Pemilihan umum yang bebas.(3)Kebebasan menyatakan pendapat,(4)Kebebasan berserikat/ berorganisasi dan beroposisi.(5)Pendidikan kewarga negaraan.Moh. Mahfud MD, Demokrasi dan Konstitusi Di Indonesia (Yogyakarta:Rineka Cipta,1993), hlm. 30. Sedangkan Mukti Fajar berpendapat bahwa ciri-ciri negara hukum adalah: (1)Asas pengakuan dan perlindungan hak-hak asasi manusia, (2)Asas legalitas, (3)Asas pembagian kekuasaan Negara, (4)Asas peradilan yang bebas dan tidak memihak (5)Asas kedaulatan rakyat.(6)Asas demokrasi, (7)Asas konstitusional. Mukthi Fajar, Tipe Negara Hukum (Malang: Bayu Media Publishing, 2003), hlm.43.

${ }^{12}$ Marwan Mas, Pengatar Ilmu Hukum (Bogor:Ghalia Indonesia, 2004), hlm. 70.

${ }^{13}$ Indonesia, Undang-Undang tentang Peradilan Agama, UU No. 54 tahun 1989, Pasal 54. 
Peradilan Agama. Adapun perkara yang hukum acaranya sudah diatur oleh undang-undang nomor 7 Tahun 1989 adalah dalam perkara perceraian dengan alasan syiqaq dan alasan zina.

Mengenai tata cara pemeriksaan perkara perceraian atas dasar alasan syiqaq diatur dalam Pasal 76 ayat (1). Dalam pasal tersebut disebutkan "syiqaq adalah perselisihan yang tajam dan terus menerus antara suami isteri". Penyelesaian perkara syiqaq merupakan pemeriksaan secara khusus (lex spesialis) dan agak menyimpang dari asas-asas umum hukum acara. ${ }^{14}$

Kekhususan dari perkara syiqaq dapat dilihat dari fungsi keluarga dalam pemeriksaan perkara tersebut. Dalam pasal 76 ayat (1) UndangUndang Nomor 7 Tahun 1989 disebutkan:

apabila perceraian didasarkan atas alasan syiqaq, maka untuk mendapatkan putusan perceraian harus didengar keterangan saksi-saksi yang berasal dari keluarga atau orang-orang yang dekat dengan suami isteri.

Dari bunyi pasal tersebut, hakim yang memeriksa perkara syiqaq diharuskan untuk mendengar dan memeriksa keluarga dekat dengan suami isteri. Jika ternyata keluarga yang dekat tidak ada atau jauh dan sulit untuk dihadirkan ke dalam persidangan, maka hakim dapat memerintahkan kepada para pihak yang berperkara untuk menghadirkan orang yang dekat dengan suami atau isteri. Pemeriksaan keluarga atau orang-orang yang dekat dengan suami isteri dalam perkara perceraian dengan alasan syiqaq adalah imperatif, oleh karena itu pemeriksaan kepada keluarga wajib dilaksanakan oleh hakim sebelum menjatuhkan putusan.

Kedudukan keluarga atau orang-orang dekat dalam perkara syiqaq adalah saksi, bukan sebagai orang yang hanya sekadar memberikan keterangan saja atau orang yang diminta oleh hakim dalam rangka upaya perdamaian para pihak yang berperkara dalam perkara gugat cerai biasa. Oleh karena kedudukan keluarga atau orang-orang dekat dengan suami isteri itu sebagai saksi, maka hakim harus mendudukan mereka secara formal dan meteriil sesuai dengan Pasal 145 dan 146 HIR. Jadi sebelum mereka memberi keterangan di muka persidangan harus disumpah terlebih dahulu. Keluarga sebagai saksi hanya berlaku dalam perkara perceraian yang didasarkan alasan perselisihan dan pertengkaran terus menerus dan ada unsur dharar, serta pecahnya tali perkawinan (syiqaq).

Kekhususan perkara syiqaq yang kedua adalah adanya keharusan mengangkat hakam. Hal ini ditegaskan dalam Pasal 76 ayat (2) UndangUndang Nomor 7 Tahun 1989, yang berbunyi:

14 Abdul Manan, Penerapan Hukum Acara Perdata di LingkunganPeradilan Agama (Jakarta: Prenada Media, 2005), hlm. 388. 
Pengadilan setelah mendengar keterangan saksi tentang sifat persengketaan antara suami isteri dapat mengangkat seorang atau lebih dari keluarga masing-masing pihak atau orang lain untuk menjadi hakam.

Tentang kapan sebaiknya para hakam itu diperiksa, hal ini kembali pada pasal 76 ayat (2) Undang-Undang Nomor 7 Tahun 1989. Dalam pasal tersebut disebutkan bahwa para hakam itu harus diperiksa setelah tahap pembuktian. Dengan demikian hasil pemeriksaan pembuktian dapat diinformasikan secara lengkap kepada hakam yang ditunjuk, terutama tentang sifat dari perselisihan dan persengketaan yang terjadi di antara suami isteri tersebut. Informasi tersebut dapat dipergunakan oleh hakam dalam usaha mendamaikan para pihak dan mengakhiri sengketa.

Perkara yang menjadi kewenangan Pengadilan Agama yang telah diatur oleh Undang-Undang Nomor 7 tahun 1989, selain syiqaq juga perkara cerai dengan alasan zina. ${ }^{15}$ Pengaturan tentang cerai dengan alasan zina terdapat pada Pasal 87 ayat (1). Pasal 87 Undang-Undang tersebut berbunyi:

Apabila permohonan atau gugatan cerai diajukan atas alasan salah satu pihak melakukan zina, sedangkan pemohon atau penggugat tidak dapat melengkapi bukti-bukti dan termohon atau tergugat menyanggah alasan tersebut, dan Hakim berpendapat bahwa permohonan atau gugatan itu bukan tiada bukti sama sekali serta upaya peneguhan alat bukti tidak mungkin lagi diperoleh baik dari pemohon atau penggugat maupun dari termohon atau tergugat, maka Hakim karena jabatannya dapat menyuruh pemohon atau penggugat untuk bersumpah.

Selanjutnya pada Pasal 88 disebutkan:

Apabila sumpah sebagaimana yang dimaksud dalam Pasal 87 ayat (1) dilakukan oleh suami, maka penyelesaiannya dapat dilaksanakan dengan cara li'an.(2) apabila sumpah sebagaimana yang dimaksud dalam pasal 87 ayat (1) dilakukan oleh isteri maka penyelesainnya dilaksanakan dengan hukum acara yang berlaku.

Dalam perkara dengan alasan zina telah diatur tentang bagaimana cara membuktikannya. Sistem pembuktian dalam pemeriksaan cerai karena alasan zina adalah sistem pembuktian yang diatur dalam AlQuran surat An-Nur ayat 4, 6 dan 7 yakni harus ada empat orang saksi yang melihat perbuatan tersebut. Apabila suami tidak dapat menghadirkan empat orang saksi maka ia dianggap dalam keadan qazaf dan hakim secara ex officio dapat memerintahkan suami untuk 
mengucapkan li'an. Lian menurut para ahli Fiqih adalah tuduhan suami kepada isteri bahwa isteri telah berbuat zina dan anak yang lahir darinya adalah bukan anak suami. Tuduhan tersebut dilakukan dengan cara bersumpah. Hal ini ditegaskan oleh Joseph Schacht sebagai berikut:

The husband affirms under oath that the wife has commited unchastity or that the child born of her is not his, and she, if the occasion arises, affirms under oath the contrary, these affirmations are made in stringent forms of a magical character. ${ }^{16}$

Problem hukum acara Peradilan Agama adalah belum dimilikinya hukum acara tersendiri. Selama ini hukum acara yang digunakan adalah hukum acara yang berlaku di Peradilan Umum, padahal jenis perkara yang menjadi kewenangan Peradilan Agama tidak sedikit yang bersifat spesifik yang penyelesaiannya tidak mungkin dengan menggunakan hukum acara di Peradilan Umum.

Kemudian disamping terdapat hukum formil yang berlaku di Pengadilan Agama terdapat juga hukum materiil. ${ }^{17}$ Sumber hukum ${ }^{18}$ dari hukum materiil Pengadilan Agama adalah bersumber dari hukum Islam. Hukum materiil yang bersumber dari hukm Islam ini ada yang sudah menjadi hukum tertulis dan ada yang belum. Adapaun hukum materiil yang sudah menjadi hukum tertulis terdiri dari :

\footnotetext{
16 Joseph Schacht, An Introduction To Islamic Law, (Oxford: Clarendon Press, 1983), p. 165 .

${ }^{17}$ Hukum materiil adalah hukum yang mengatur hubungan nantara anggota masyarakat
} yang berlaku umum tentang apa yang dilarang apa yang dilarang dan apa yang dibolehkan untuk dilakukan.Mas, loc. cit.

${ }^{18}$ Sumber hukum adalah bahan-bahan yang digunakan oleh pengadilan sebagai dasar dalam memutus perkara.Peter Mahmud Marzuki, Pengantar Ilmu Hukum (Jakarta: Kencana Prenada Media Group, 2008), hlm.301.Sumber hukum yang dikenal dalam ilmu hukum ada 2 macam, yakni sumber hukum materiil dan sumber hukum formil. Sumber hukum materiil adalah sumber hukum yang menentukan isi suatu peraturan atau kaidah hukum yang mengikat setiap orang. Bagir Manan, Beberapa Masalah Hukum Tata Neagara Indonesia (Alumni, Bandung,1997), hlm.61. Sedangkan sumber hukum formal adalah sumber hukum yang berupa hukum yang ditetapkan oleh Negara atau yang diakui sebagai kaidah hukum.Kumpulan kaidah ini disebut hukum positif.

Sumber hukum formal atau hukum positif di Indonesia terdiri dari : hukum perundangundangan, hukum yurisprudensi, hukum kebiasaan, hukum adat, hukum agama yang dinyatakan berlaku sebagai hukum positif. Sudikno Mertokusumo berpendapat bahwa sumber hukum sering digunakan dalam beberapa arti,yaitu: (a) sebagai asal hukum, sebagai sesuatu yang merupakan permulaan hukum, misalnya kehendak Tuhan, akal manusia, jiwa bangsa dan sebagainya; (b) menunjukan hukum terdahulu, yang memberi bahan-bahan kepada hukum yang sekarang berlaku, hukum Paris, hukum Romawi; (c) sebagai sumber berlakunya, yang memberi kekuatan berlaku secara formal kepada peraturan hukum (penguasa, masyarakat); (d) sebagai sumber untuk mengenal hukum, misalnya dokumen, undang-undang, lontar, batu bertulis dan sebagainya; (e) sebagai sumber terjadinya hukum, sumber yang menimbulkan hukum.Mertokusumo, op. cit., hlm.76. Cakupan pembahasan sumber hukum adalah some of the deepest problems of legal philosophy. George Whitecross, A Text Book of Jurisprudence,

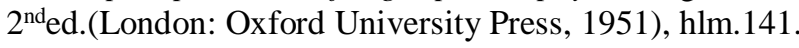


1) Undang-Undang Nomor 22 Tahun 1946 jo. Undang-Undang Nomor 32 Tahun 1954 Tentang Nikah, Talak, Cerai dan Rujuk,

2) Undang-Undang Nomor 1 Tahun 1975 Tentang Perkawinan

3) Peraturan Pemerintah Nomor 9 Tahun 1975 Tentang Pelaksanaan Undang-Undang Nomor 1 Tahun 1974,

4) Undang-Undang Nomor 7 Tahun 1992 Tentang Perbankan yang telah diubah dengan Undang-Undang Nomor 10 Tahun 1998 ,

5) Undang-Undang Nomor 23 Tahun 1999 Tentang Bank Indonesia,

6) Undang-Undang Nomor 38 Tahun 1999 Tentang Pengelolaan Zakat,

7) Undang-Undang Nomor 41 Tahun 2004 Tentang Wakaf,

8) Undang-Undang Nomor 19 Tahun 2008 Tentang Surat Berharga Syari'ah Negara,

9) Undang-Undang Nomor 21 Tahun 2008 Tentang Perbankan Syariah,

10) Undang-Undang Nomor 23 Tahun 2002 Tentang Perlindungan Anak,

11) Undang-Undang Nomor 24 Tahun 2004 Tentang Penghapusan Kekerasan Dalam Rumah Tangga,

12) Peraturan Pemerintah Nomor 28 Tahun 1977 Tentang Perwakafan Tanah Milik

13) Peraturan Bank Indonesia yang berkaitan dengan ekonomi syari'ah,

14) Yursiprudensi

15) Qonun Aceh

Adapun yang belum menjadi hukum tertulis adalah:

1) Kompilasi Hukum Islam,

2) Kompilasi Hukum Ekonomi Syariah,

3) Fatwa Dewan Syariah Nasional Majelis Ulama Indonesia

Jenis hukum materiil yang paling banyak digunakan oleh hakim sebagai dasar pertimbangan putusan di Peradilan Agama adalah Kompilasi Hukum Islam. Tetapi Kompilasi Hukum Islam tersebut meskipun sudah ditulis tetapi belum merupakan hukum tertulis karena Kompilasi Hukum Islam tidak ditetapkan oleh Negara. ${ }^{19}$ Peradilan Agama adalah Peradilan Negara, seharusnya hukum materiil yang digunakan adalah hukum yang dibentuk oleh Negara. Hal tersebut merupakan salah satu problem hukum materiil di Peradilan Agama.

19 A.Hamid S.Attamimi, "Kedudukan Kompilasi Hukum Islam dalam Sistem Hukum Nasional," dalam Dimensi Hukum Islam Dalam Sistem Hukum Nasional, ed. Amrullah Ahmad (Jakarta: Gema Insani Press, 1996), hlm. 153. 


\section{b. Aparat Hukum Peradilan Agama}

Menurut Jimly Asshiddiqie, dalam lingkungan internal organisasi pengadilan ada tiga jabatan yang bersifat fungsional yakni, hakim, panitera dan pegawai adminsitrasi lainnya. ${ }^{20}$ Untuk lingkungan Peradilan Agama aparat peradilannya terdiri dari pejabat fungsional dan pejabat struktural. Aparat peradilan agama yang terkait langsung dengan bidang yudisial adalah hanya para pejabat fungsional yakni hakim, panitera dan juru sita. Oleh karenanya yang akan penulis bahas dalam tulisan ini hanya ketiga pejabat tersebut.

\section{(1) Hakim}

Hakim menurut ketentuan pasal 19 Undang-Undang Nomor 48 Tahun 2009 Tentang Kekuasaan Kehakiman adalah pejabat negara yang melakukan kekuasaan kehakiman yang diatur dalam undang-undang. Istilah pejabat disini dipakai untuk menegaskan status hukum hakim sebagai pejabat negara. Oleh karenanya tidak boleh diberlakukan seperti pegawai negeri pada umumnya. Dalam Pasal 11 Undang-Undang Nomor 7 Tahun 1989 disebutkan : Hakim adalah pejabat yang melaksanakan tugas kekuasaan kehakiman. Oleh karena itu wajar apabila undangundang menentukan syarat, pengangkatan, pemberhentian serta sumpah yang sesuai dengan jabatan tersebut. ${ }^{21}$

Mengenai persyaratan yang harus dipenuhi agar seseorang dapat menjadi hakim di Pengadilan Agama diatur dalam Pasal 13 UndangUndang Nomor 7 Tahun 1989. Ketetntuan persyaratan tersebut sama dengan persyaratan menjadi hakim di Peradilan Umum maupun Peradilan Tata Usaha Negara. Hanya terdapat variasi kecil dibidang disiplin kesarjanaan. Pada lingkungan Peradilan Umum dan Tata Usaha Nagara, disyaratkan sarjana hukum atau sarjana yang memiliki keahlian di bidang tata usaha Negara. Sedang syarat kesarjanaan di Pengadilan Agama adalah sarjana syari'ah atau sarjana hukum yang menguasai hukum Islam. Syarat yang paling berbeda dengan hakim di lingkungan peradilan lain adalah adanya syarat bagi hakim Peradilan Agama harus beragama Islam. Pada peradilan lain, agama tidak dijadikan sebagai syarat.

Tentang syarat beragama Islam bagi hakim Pengadilan Agama, ada yang beranggapan sebagai syarat yang mengandung cacat diskriminasi. Sebab dengan syarat tersebut, hukum telah menutup pintu bagi yang non Islam untuk menjadi hakim di lingkungan Peradilan Agama. Padahal lingkungan Peradilan Agama sesuai dengan ketentuan Pasal 13 Undang-

20 Jimly Asshiddiqie, Pokok-Pokok Hukum Tata Negara Indonesia Pasca Reformasi (Jakarta: Bhuana Ilmu Populer, 2007), hlm. 543.

${ }^{21}$ M.Yahya Harahap, Kedudukan Kewenangan Dan Acara Peradilan Agama, (Jakarta: Sinar Grafika, 2007), hlm.117. 
Undang Nomor 48 Tahun 2009, termasuk Peradilan Negara. Dengan demikian Peradilan Agama adalah milik semua bangsa tanpa kecuali. Wajar dan semestinya terbuka untuk setiap warga negara. Dari satu segi pandangan tersebut memang benar, akan tetapi ditinjau dari sudut pendekatan "kekhususan" yang didasarkan pada undang-undang, Peradilan Agama memiliki ciri khusus yang sangat erat dengan hal-hal sebagai berikut: Pertama faktor personalitas ke-Islaman, kedua faktor hukum yang diterapkan, yakni khusus hukum Islam.

Berdasarkan kedua faktor tersebut maka wajar jika orang yang akan menegakkan hukum dalam Peradilan Agama disyaratkan beragama Islam. Kemudian dari segi etika, rasanya janggal jika hukum yang akan diterapkan adalah hukum Islam dan hukum tersebut akan diperlakukan bagi yang beragama Islam, sedang Hakim yang menerapkan hukum itu tidak beragama Islam.

Syarat-syarat selengkapnya untuk menjadi hakim Pengadilan Agama adalah sebagai berikut: (1) warga negara Indonesia, (2) beragama Islam, (3) bertakwa kepada Than Yang Maha Esa, (4) setia kepada Pancasila dan Undang-Undang Dasar Negara Republik Indonesia Tahun 1945, (5) sarjana syari'ah, sarjana hukum Islam atau sarjana hukum yang menguasai hukum Islam, (6) lulus pendidikan hakim, (7) mampu secara rohani dan jasmani untuk menjalankan tugas dan kewajiban, (8) berwibawa, jujur, adil, dan berkelakuan tidak tercela, (9) berusia paling rendah 25 (dua puluh lima) tahun, dan paling tinggi 45 (empat puluh lima) tahun, dan (10) tidak pernah dijatuhi pidana penjara karena melakukan kejahatan berdasarkan putusan pengadilan yang telah memperoleh kekuatan hukum tetap.

Selain syarat ke-Islaman, tidak ada perbedaan dengan persyaratan hakim pada umumnya, terutama di lingkungan Peradialn Umum dan Tata Usaha Negara. Semua syarat yang ditentukan dalam Pasal 13 UndangUndang Nomor 50 Tahun 2009, merupakan syarat yang bersifat kumulatif. Semua harus terpenuhi, tidak boleh kurang. Satu saja syarat tidak terpenuhi maka pengangkatan hakim menjadi batal.

Selanjutnya mengenai pengangkatan hakim. Pengangkatan yang dimaksud dengan pengangkatan dalam tulisan ini adalah berhubungan dengan instansi yang berwenang menetapkan pengangkatan hakim di lingkungan Peradilan Agama. Mengenai hal tersebut diatur dalam Pasal 15 Undang-Undang Nomor 50 Tahun 2009 yang isinya sama dengan ketentuan Pasal 15 Undang-Undang Nomor 49 Tahun 2009 Tentang Peradilan Umum dan Undang-Undang Nomor 51 Tahun 2009 Tentang Peradilan Tata Usaha Negara. Dengan demikian maka pengangkatan hakim di Peradilan Agama sama persis dengan pengangkatan hakim di lingkungan Peradilan Umum dan Peradilan Tata Usaha Negara. Hal ini merupakan salah satu isyarat tentang kesamaam derajat antara semua lingkungan peradilan sebagai peradilan negara.

Menurut Pasal 15 Undang-Undang Nomor 50 Tahun 2009 yang berwenang mengangkat hakim di Lingkungan Peradilan Agama ialah 
Presiden selaku kepala Negara atas usulan Mahkamah Agung. Pengangkatan oleh Presiden dalam kualitas kedudukan selaku Kepala Negara.

Dari prosedur tersebut, maka terlihat bahwa yang berwenang mengangkat hakim melibatkan dua unsur aparat negara. Hal ini memperlihatkan betapa terhormatnya kedudukan jabatan hakim. Sudah selayaknya para hakim menjunjung tinggi kehormatan dan kepercayaan tersebut.

Berikutnya mengenai pemberhentian hakim. Mengenai pemberhentian hakim, sama prosedurnya dengan pengangkatan hakim. Pemberhentian hakim dilakukan oleh Presiden selaku Kepala Negara atas usul Mahkamah Agung dan/atau Komisi Yudisial melalui Ketua Mahkamah Agung.

Undang-undang mengenal dua macam jenis pemberhentian, yakni pemberhentian dengan hormat dan pemberhentian dengan tidak hormat. Setiap juenis pemberhentian didasarkan pada alasan-alasan tertentu.

a) Pemberhentian dengan hormat. Pemberhentian dengan hormat diatur dalam Pasal 18 Undang-Undang Nomor 50 Tahun 2009. Alasan pemebrehentian hakim dari jabatannya dengan hormat adalah: (1) atas permintaan sendiri secara tertulis; (2) sakit jasmani atau rokhani secara terus menerus ; (3) telah berumur 65 (enam puluh lima) tahun bagi hakim tingkat pertama dan 67 (enam puluh tujuh) tahun bagi hakim Pengadilan Tinggi Agama; (4) ternyata tidak cakap dalam menjalankan tugas.

b) Pemberhentian tidak dengan hormat. Alasan pemberhentian tidak dengan hormat diatur dalam Pasal 19 Undang-Undang Nomor 50 tahun2009. Alasan tersebut adalah: (1) dipidana penjara karena bersalah melakukan kejahatan berdasarkan putusan pengadilan yang telah memperoleh kekuatan hukum tetap: (2) melakukan perbuatan tercela; (3) melalaikan kewajiban dalam menjalankan tugas pekerjaannya terus menerus selama 3 (tiga) bulan; (4) melanggar sumpah atau janji jabatan; (5) melanggar larangan sebagaimana dimaksud Pasal 17; dan atau (6) melanggar kode etik dan Pedoman Prilaku Hakim.

Larang bagi hakim menurut Pasal 17 adalah: (1) hakim tidak boleh merangkap sebagai pelaksana putusan (2) hakim dilarang merangkap menjadi wali pengampu, dan jabatan yang berkaitan dengan suatu perkara yang diperiksa olehnya, (3) merangkap sebagai pengusaha, (4) tidak boleh merangkap sebagai penasehat hukum.

Usul pemberhentian yang disebabkan hakim dipidana penjara diajukan oleh Ketua Mahkamah Agung. Usul pemberhentian disebabkan hakim melakukan perbuatan tercela diusulkan oleh Mahkamah Agung dan/atau Komisi Yudisial. Usul pemberhentian disebabkan hakim melalaikan kewajiban, melanggar sumpah atau janji jabatan dan melanggar larangan diajukan oleh Mahkamah Agung. Usul 
pemberhentian yang disebabkan hakim melanggar kode etik dan pedoman prilaku hakim diajukan oleh Komisi Yudisial.

Mengenai tata cara pemberhentian tidak dengan hormat terdapat ketentuan bahwa sebelum Mahkamah Agung dan atau Komisi Yudisial mengajukan usul pemberhentian, hakim pengadilan mempunyai hak untuk membela diri di hadapan Majelis Kehormatan Hakim.

Hakim sebagai salah satu komponen Peradilan Agama bertugas untuk memeriksa, memutus dan menyelesaikan perkara yang menjadi kewenangan Peradilan Agama. ${ }^{22}$ Tugas pokok hakim adalah mengadili, memeriksa dan memutus perkara yang yang dihadapkan kepadanya, sehingga tidak ada alasan bagi hakim untuk menolak perkara dengan alasan hukumnya belum ada atau tidak jelas.

Ada tiga tahapan yang harus dilakukan oleh hakim dalam memeriksa dan mengadili serta menjatuhkan putusan, yakni sebagai berikut: ${ }^{23}$

a) Tahap mengkonstatir.

Pada tahap ini, hakim mengkonstatir atau melihat untuk menentukan ada tidaknya suatu peristiwa yang diajukan kepada hakim. Untuk memastikan hal tersebut, maka diperlukan pembuktian, dan oleh karena itu hakim harus bersandarkan pada alat-alat bukti yang sah menurut hukum. Alat bukti dalam perkara perdata diatur dalam pasal $164 \mathrm{HIR} /$ Pasal $284 \mathrm{RBg}$. Menurut pasal tersebut alat bukti terdiri dari bukti tertulis, saksi, persangkaan, pengakuan dan sumpah.

b) Tahap mengkualifikasi

Pada tahap ini hakim mengkualifisir dengan menilai peristiwa kongret yang telah dianggap benar-benar terjadi itu, termasuk hubungan hukum apa atau hubungan yang bagaimana atau menemukan hukum untuk peristiwa-peristiwa tersebut. Dengan kata laian mengkwalifisir berarti mengelompokan atau menggolongkan peristiwa kongkret tersebut masuk dalam kelompok atau golongan peristiwa hukum.

Jika peristiwanya sudah terbukti dan peraturan hukumnya jelas dan tegas, maka penerapan hukumnya akan mudah, tetapi jika hukumnya tidak jelas atau tidak tegas hukumnya, maka hakim bukan lagi harus menemukan hukumnya saja, tetapi lebih dari itu hakim haris menciptakan hukum, yang tentu saja tidak boleh bertentangan dengan keseluruhan sistem hukum perundangundngan dan memenuhi pandangan serta kebutuhan masyarakat.

c) Tahap mengkonstituir

Pada tahap ini, hakim menetapkan hukumnya terhadap peristiwa tersebut dan memberi keadilan pada para pihak yang bersangkutan. Keadilan yang diputuskan oleh hakim bukanlah

${ }^{22}$ Harahap, op. cit., hlm. 100

${ }^{23}$ Mertokusumo, op. cit., hlm. 92-94 
produk dari intlektualitas hakim, tetapi merupakan semangat hakim itu sendiri.

Dalam mengadili suatu perkara, hakim harus menentukan hukumnya in konreto terhadap peristiwa tertentu sehingga putusan hakim tersebut dapat menjadi hukum (judge made law). Disini hakim menggunakan silogisme, yaitu menarik suatu kesimpulan dari premis mayor berupa aturan hukumnya dan premis minor berupa perbuatan atau tindakan. Sebagai konklusinya adalah hukumannya.

Problem hakim dalam melaksanakan tugas adalah masih banyaknya hakim yang tidak mau berfikir falsafati, hakim hanya memahami teks-teks hukum yang nomatif, hakim tidak memperhatikan filsafat hukum yang melatari dan menjadi inti dari adanya hukum tersebut, yakni keadilan ${ }^{24}$.

\section{(2) Panitera}

Panitera adalah pegawai negeri sipil yang menyandang jabatan fungsional sebagai administratur perkara yang bekerja berdasarkan sumpah jabatan untuk menjaga kerahasiaan setiap perkara. ${ }^{25}$

a) Fungsi Panitera

Pada prinsipnya managemen peradilan di Indonesia dipimpin oleh seorang panitera. Oleh karena itu seorang panitera harus mampu menjalankan fungsi managerial dan fungsi operatif. Fungsi managerial mengatur semua kegiatan dan keikutsertaan karyawan dalam kegiatan organisasi. Sedangkan fungsi operatif menentukan jumlah dan mutu tenaga kerja sesuai dengan kebutuhan untuk mencapai tujuan organisasi. ${ }^{26}$

Fungsi Panitera pada dasarnya mencakup lima hal :

(1) Menyusun kegiatan administrasi perkara serta melaksanakan kordinasi dan sinkronisasi yang berkaitan dengan persidangan.

(2) Mengurus daftar perkara, administrasi perkara, administrasi keuangan perkara dan administrasi pelaksanaan putusan perkara perdata.

(3) Menyusun stastistik perkara, dokumentasi perkara, laporan perkara dan yurisprudensi

(4) Lain-lain berdasarkan peraturan perundang-undangan.

b) Tugas Panitera

Tugas Panitera sesuai dengan ketentuan Pasal 98 Undang-Undang Nomor 50 Tahun 2009 Tentang Perubahan Kedua atas UndangUndang Nomor 7 Tahun 1989 Tentang Peradilan Agama, adalah

\footnotetext{
${ }^{24}$ Ahmad Zaenal Fanani, "Berfikir Falsafati dalam Putusan Hakim," Varia Peradilan 304 (Maret, 2011), hlm. 55.

${ }^{25}$ Asshiddiqie, Op.Cit. hal 542

${ }^{26}$ Mahkamah Agung Republik Indonesia, Panitera Pengadilan, Tugas, Fungsi, Dan Tanggung Jawab,(Jakarta: Mahkamah Agung, 2007), hlm.19.
} 
sebagai berikut: (1) melaksanakan penetapan atau putusan Pengadilan, (2) membuat daftar semua perkara yang diterima di kepanitraan, (3) membuat salinan atau turunan penetapan atau putusan Pengadilan menurut ketentuan peraturan perundangundangan yang berlaku. Tugas lain seorang panitera adalah membantu hakim dengan menghadiri dan mencatat jalannya sidang Pengadilan. ${ }^{27}$

Berdasarkan uraian tersebut maka tugas Panitera secara lebih rinci adalah sebagai berikut:

1) Tugas Panitera Bidang Persidangan:

Tugas dalam sidang, Panitera bertugas mengikuti dan mencatat jalannya persidangan. Panitera yang berhalangan untuk mengikuti persidangan dapat diganti oleh seorang Panitera Pengganti. Sebagai pejabat yang mengikuti dan mencatat jalannya persidangan Panitera Pengganti tidak berada di lini komando Panitera, akan tetapi akan melaksanakan perintah Hakim/Majelis Hakim yang bersidang.

Adapun tugas-tugas penitera di bidang persidangan meliputi halhal sebagai berikut :

(a) Membantu hakim dengan menghadiri dan mencatat jalannya sidang pengadilan.

(b) Menyusun berita acara persidangan.

(c) Memberitahukan putusan verstek dan putusan di luar hadir.

(d) Melegalisir surat-surat yang akan dijadikan bukti dalam persidangan.

(e) Mengirimkn berkas perkara yang dimohonkan banding, kasasi dan peninjauan kembali.

2) Tugas Panitera Bidang Eksekusi

Sebagai pejabat yang melaksanakan eksekusi perkara perdata, Panitera hanya mempunyai hubungan dengan Ketua Pengadilan untuk melaksnakan perintah yang diwujudkan dalam bentuk penetapan Ketua Pengadilan, dan dalam hal Panitera berhalangan maka akan diganti oleh Juru Sita. Dalam hal ini Panitera bertanggung jawab kepada Ketua Pengadilan.

Tugas Panitera dalam bidang eksekusi diatur dalam Pasal 98 Undang-Undang Nomor 7 Tahun 1989. Untuk melaksanakan putusan pengadilan/ekseksui Panitera harus memperhatikan asasasas eksekusi. $^{28}$

(3) Juru Sita

Pada setiap Pengadilan Agama ditetapkan adanya juru sita dan juru sita pengganti .Tugas Juru Sita sebagaimana diatur dalam Pasal

27 Direktorat Jenderal Peradilan Agama Mahkamah Agung Republik Indonesia, Pedoman Pembinaan Peradilan Agama, (Jakarta: Mahkamah Agung Republik Indonesia, 2007), hlm. 34

${ }^{28}$ Mahkamah Agung Republik Indonesia, op.cit., hlm.40 
103 Undang-Undang Nomor 50 Tahun 2009 adalah sebagai berikut : (1) melaksanakan semua perintah yang diberikan oleh Ketua Sidang, (2) menyampaikan pengumuman, teguran, dan pemberitahuan putusan Pengadilan berdasarkan ketentuan undang-undang, (3) melakukan penyitaan atas perintah Ketua Pengadilan, (4) membuat berita acara, yang salinan resminya diserahkan kepada pihak-pihak yang berkepentingan.

Juru sita berwenang untuk melakukan tugasnya di daerah hukum Pengadilan Agama dimana Juru Sita tersebut bertugas. Hal tersebut diatur dalam Pasal 103 ayat 2 Undang-Undang Nomor 7 tahun 1989. Dengan demikian ketika Juru Sita harus memanggil orang yang berada di wilayah luar Pengadilan Agama dimana dia bertugas, maka ia harus minta bantuan ke juru sita Pengadilan Agama wilayah lain.Prosedur yang sperti ini akan memakan waktu yang cukup lama sehingga akan menghambat penyelesaian perkara.

Juru Sita/Juru sita pengganti dalam kontek kelembagaan bertanggung jawab kepada Ketua Pengadilan Agama, sedangkan secara administratif Juru Sita/Juru Sita Pengganti bertanggung jawab kepada Panitera. Hal tersebut diatur dalam Pasal 8 Keputusan Ketua Mahkamah Agung Republik Indonesia Nomor: KMA/055/SK/X/1996 yang menentukan sebagai berikut:

(1) Dalam hal ditunjuk melakukan ekseksusi,Juru Sita atau Juru Sita Pengganti bertanggung jawab kepada Ketua Pengadilan.

(2) Dalam hal melaksanakan perintah pemanggilan/penyampaian pengumuman, teguran, protes-protes dan pemberitahuan, Juru Sita atau Juru Sita Pengganti bertanggung jawab kepada Ketua Pengadilan/Ketua Sidang

(3) Dalam hal melakukan sita, Juru Sita atau Juru Sita Pengganti bertanggung jawab kepada Ketua Pengadilan/Ketua Sidang.

\section{Tujuan Lembaga Peradilan Agama}

Sesuai dengan teori sistem hukum, bahwa salah satu komponen dari sistem hukum adalah adanya tujuan dari sistem hukum tersebut. Karena Peradilan Agama sebagai sistem hukum maka Peradilan Agama juga harus memiliki tujuan yang jelas. Adapun tujuan Peradilan Agama sama dengan tujuan didirikannya empat lingkungan peradilan di Indonesia yakni menegakkan hukum dan keadilan berdasarkan Pancasila sesuai dengan ketentuan pasal 2 ayat (2) Undang-Undang Nomor 48 Tahun 2009 Tentang Kekuasaan Kehakiman.

\section{Penutup}

1. Kesimpulan

a. Peradilan Agama memiliki beberapa komponen yakni: pertama aturan hukum yang terdiri dari hukum materiil dan hukum formil, kedua aparat peradilan terdiri dari Hakim, Panitera dan Juru Sita. 
b. Masing-masing komponen tersebut memiliki fungsi dan tugas sendiri-sendiri. Tetapi meskipun memiliki tugas sendiri-sendiri antara komponen yang satu dengan lainnya saling tergantung dan bekerja sama untuk mencapai satu tujuan yakni terciptanya hukum dan keadilan.

2. Saran

a. Perlu dibentuk hukum formil/acara khusus Peradilan Agama karena ada beberapa hukum materiil Peradilan agama memiliki spesifikasi sendiri yang berbeda dengan hukum materiil yang menjadi kewenangang Peradilan Umum.

b. Kompilasi Hukum Islam sebagai hukum materiil yang digunakan di pengadilan Agama supaya segera dijadikan hukum tertulis di Indonesia.

Untuk mencapai keadilan hakim dalam menjalankan tugasnya tidak cukup berfikir normative tetapi pada kondisi tertetntu perlu berfikir secara filosofis. 


\section{Daftar Pustaka}

\section{Buku}

Amirin, Tatang M. Pokok-Pokok Teori Sistem. Jakarta: Rajawali Pers, 1996.

Asshiddiqie, Jimly. Konstitusi dan Konstitusionalisme Indonesia. Jakarta: Sinar Grafika, 2004.

- Pokok-Pokok Hukum Tata Negara Indonesia Pasca Reformasi. Jakarta: Bhuana Ilmu Populer, 2007.

Attamimi, A. Hamid S. "Kedudukan Kompilasi Hukum Islam dalam Sistem Hukum Nasional." dalam Dimensi Hukum Islam Sistem Hukum Nasional. Ed. Amrullah Ahmad. Jakarta: Gema Insani Press, 1996.

Azizy, Qodri. Eklektisisme Hukum Nasional Kompetisi Antara Hukum Islam dan Hukum Umum. Yogyakarta: Gama Media, 2002.

Direktorat Jenderal Peradilan Agama Mahkamah Agung Republik Indonesia. Pedoman Pembinaan Peradilan Agama. Jakarta: Mahkamah Agung Republik Indonesia, 2007.

Fajar, Mukthi. Tipe NegaraHukum.Malang: Bayu Media Publishing, 2003.

Fuadi, Munir. Teori Negara Hukum Modern (Rechttstaat). Bandung: PT Refika Aditama, 2009.

Harahap, Yahya.Kedudukan Kewenangan Dan Acara Peradilan Agama.Jakarta: Sinar Grafika, 2007.

Ismail Saleh. Majalah Hukum Badan Pembinaan Hukum Nasional. Edisi Khusus, no. 119. (Jakarta: Departemen Kehakiman Republik Indonesia).

Lubis, Solly. Ilmu Pengetahuan Perundang-Undangan. Bandung: Mandar Maju, 2009.

Mahkamah Agung Republik Indonesia. Panitera Pengadilan Tugas Fungsi dan Tanggungjawab. Jakarta: Mahkamah Agung Republik Indonesia, 2007.

Manan, Abdul.Penerapan Hukum Acara Perdata di LingkunganPeradilan Agama.Jakarta: Prenada Media, 2005.

Manan, Bagir Beberapa Masalah Hukum Tata Neagara Indonesia. Bandung: Alumni, 1997. 
Marzuki, Peter Mahmud.Pengantar Ilmu Hukum.Jakarta: Kencana Prenada Media Group, 2008.

Mas, Marwan.Pengantar Ilmu Hukum. Bogor: Ghalia Indonesia, 2004.

MD, Moh. Mahfud. Demokrasi dan Konstitusi Di Indonesia. Yogyakarta: Rineka Cipta, 1993.

Mertokusumo, Sudikno. Mengenal Hukum Suatu Pengantar.Yogyakarta: Liberty, 1991.

Rasjidi, Lili,dan I.B.Wyasa Putra.Hukum Sebagai Suatu Sistem. Bandung:Mandar Maju, 2003.

Schacht, Joseph. An Introduction to Islamic Law. Oxford: Clarendon Press, 1987.

Soekanto, Soerjono dan Purnadi Purbacaraka. Sendi-Sendi Ilmu Hukum. Bandung: Citra Aditya Bakti, 1993.

Soemitro, Rochmat.Masalah Peradilan Administrasi dan Hukum Pajak diIndonesia. Bandung: Eresco, 1976.

Whitecross, George. A Text Book of Jurisprudence. $2^{\text {nd }}$ ed. London: Oxford University Press, 1951.

Winardi.Pengantar Tentng Teori Sistem dan Analisis Sistem.Bandung: Mandar Maju, 1990.

\section{Artikel}

Fanani, Ahmad Zaenal. "Berfikir Falsafati dalam Putusan Hakim." Varia Peradilan 304 (Maret, 2011).

\section{Peraturan Perundang-undangan}

Indonesia. Undang-Undang tentang Peradilan Agama. Undang-Undang Nomor 7 tahun 1989, LN. No. 49 tahun 1989, TLN No. 3400. 